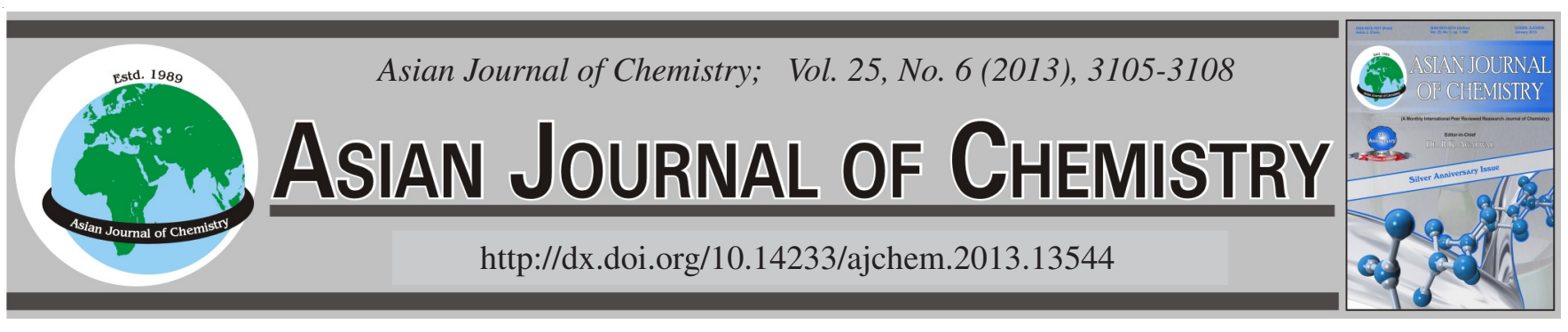

\title{
Synthesis, Characterization and Antioxidant Studies on 4-Phenyl-1,3,5-triazine-2,6-diamine Schiff Bases and Their Nickel(II), Copper(II) and Zinc(II) Complexes
}

\author{
Abdulaziz Ali ${ }^{*}$, Norbani Abdullah and Mohd Jamil MaAh
}

Department of Chemistry, Faculty of Science, University of Malaya, 50603 Kuala Lumpur, Malaysia

*Corresponding author: E-mail: abomaz1389@yahoo.com

\begin{abstract}
The synthesis, characterization, thermogravimetric and antioxidant activity of Schiff bases derived from 4-phenyl-1,3,5-triazine-2,6diamine and 3,5-di-tert-butylsalicyladehyde $\left(\mathrm{H}_{2} \mathrm{~L}\right)$ with their nickel(II), copper(II) and zinc(II) complexes are reported. The structures of the Schiff bases and the metal complexes wer characterized by elemental analyses (CHN), Fourier transform infrared spectroscopy (FTIR) and ultraviolet-visible spectroscopy (UV-VIS). Additionaly, ${ }^{1} \mathrm{H}$ - and ${ }^{13} \mathrm{C}$-nuclear magnetic resonance spectroscopy (NMR) were recorded for the Schiff bases, while thermogravimetric analysis was recorded for the complexes. Spectral studies reveal that the ligands were acting as tetradentate chelating agents and coordinated to the metal center via deprotonated phenolate oxygen and azomethine nitrogen atoms in a 1:1 ligand to metal ratio. The antioxidant activities of the ligand and the metal complexes were examined using the DPPH radical scavenging method. The results show that the ligand exhibit higher radical scavenging ability than the metal complexes.
\end{abstract}

Key Words: Synthesis, Antioxidant, Ni(II), Cu(II), Zn(II), Complexes, Schiff base.

\section{INTRODUCTION}

Schiff bases are organic compounds which contain the azomethine group $(-\mathrm{C}=\mathrm{N}-)$. These compounds are synthesized by the reaction of a primary amine and an active carbonyl compound (aldehyde or ketone) ${ }^{1-3}$.

A great deal of information regarding the properties of synthetic Schiff bases of potential biological interest has arisen during the last few years ${ }^{4,5}$, different classes of organic compounds containing rich conjugated system can be observed when these compounds contain hydroxyl groups attached to aromatic rings. For example, compounds containing an azomethine group $(-\mathrm{CH}=\mathrm{N}-)$ known as Schiff bases are formed by the condensation of a primary amine with carbonyl compounds. Schiff bases obtained from aromatic aldehydes and aromatic amines have an effective conjugation system and quite stable. Schiff bases are important compounds owing to their wide range of biological activities and industrial application. They have been found to posses the pharmacological activities such as anticancer ${ }^{6}$, antimicrobial ${ }^{7}$, antiinflammatory ${ }^{8}$ and antioxidants $^{9,10}$. Such activities may be related to the structural arrangements of the ligands and to the nature of the substituent groups $^{11}$.

In this work, we are encouraged to synthesize triazine Schiff bases containing hydroxyl groups attached to the aromatic ring (Fig. 1), along with their nickel, copper and zinc

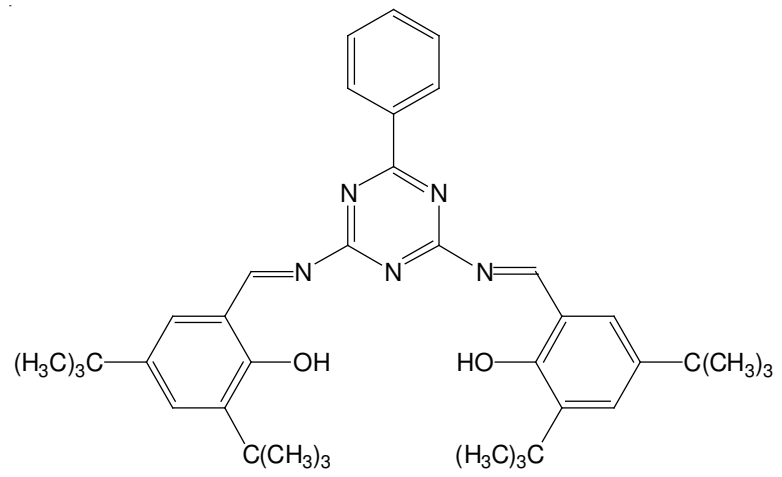

Fig. 1. Proposed structures of the ligand $\mathrm{H}_{2} \mathrm{~L}$

complexes. The novel compounds were characterized on the bases of elemental analysis, IR, ${ }^{1} \mathrm{H}$ and ${ }^{13} \mathrm{C}$ NMR spectroscopy, UV-VIS as well as thermogravimetric analysis (TGA) with a view to further investigating the radical scavenging abilities of these novel compounds using the DPPH method.

\section{EXPERIMENTAL}

4-Phenyl-1,3,5-triazine-2,6-diamine $\left(\mathrm{C}_{6} \mathrm{H}_{9} \mathrm{~N}_{5}, \mathrm{FW} 187.21\right)$, 3,5-di-tert-butylsalicyl-aldehyde $\left(\mathrm{C}_{15} \mathrm{H}_{22} \mathrm{O}_{2}, \mathrm{FW} 234.34\right)$, triethylamine, copper(II) acetate monohydrate $\left(\mathrm{CuC}_{4} \mathrm{H}_{6} \mathrm{O}_{4} \cdot \mathrm{H}_{2} \mathrm{O}\right.$; FW 199.65), nickel(II) acetate tetrahydrate $\left(\mathrm{NiC}_{4} \mathrm{H}_{6} \mathrm{O}_{4} \cdot 4 \mathrm{H}_{2} \mathrm{O}\right.$; FW 248.86), zinc acetate dihydrate $\left(\mathrm{C}_{4} \mathrm{H}_{6} \mathrm{O}_{4} \mathrm{Zn} \cdot 2 \mathrm{H}_{2} \mathrm{O}\right.$, FW 
219.50) and DPPH. These chemicals and common organic solvents were commercially available and used as received.

IR spectra were recorded with a Perkin-Elmer FT-IR spectrophotometer model Spectrum 2000 using $\mathrm{KBr}$ pellets as support in the range $4000-370 \mathrm{~cm}^{-1} .{ }^{1} \mathrm{H}$ and ${ }^{13} \mathrm{C}$ NMR spectra were recorded at room temperature on a JEOL ECA-400 spectrometer, operating with a frequency of $400 \mathrm{MHz}$, using DMSO- $d_{6}$ as solvent. Electronic spectra, in DMSO solution, were obtained using a Varian 50 conc UV-visible spectrophotometer over the wavelength range $200-800 \mathrm{~nm}$. Thermogravimetric analysis was carried out on Perkin Elmer Precisely TGA 4000 thermogravimetric analyzer. The instrument was adjusted at a heating rate of $20{ }^{\circ} \mathrm{C} / \mathrm{min}$. The heating was performed from $50-900{ }^{\circ} \mathrm{C}$.

The DPPH free radical scavenging assay was performed in triplicate and the average value was obtained. All determinations were made using the Infinite ${ }^{\circledR} 200$ PRO plate reader (TECAN, Männedorf, Switzerland).

\section{Synthesis of the ligand}

$\mathbf{H}_{2} \mathbf{L}$ : A solution of 3,5-di-tert-butylsalicylaldehyde ( $2 \mathrm{~g}$, $8.53 \mathrm{mmol})$ and 4 phenyl-1,3,5-triazine-2,6-diamine $(0.79 \mathrm{~g}$, $4.21 \mathrm{mmol}$ ) was mixed and stirred under reflux for $2 \mathrm{~h}$. The pale yellow powder formed was filtered and recrystallized from ethanol. It was dried in an oven at $80{ }^{\circ} \mathrm{C}$ for $0.5 \mathrm{~h}$. Selected FT-IR data $\left(\mathrm{KBr}, v_{\max }, \mathrm{cm}^{-1}\right): 3329(\mathrm{~m},-\mathrm{OH}), 2923(\mathrm{~m}, \mathrm{C}-\mathrm{H})$, 1612 (s, C = N), 1273 (s, C-O).

General method for synthesis of the metal complexes: A solution of $\mathrm{H}_{2} \mathrm{~L}(0.50 \mathrm{~g}, 0.81 \mathrm{mmol})$ in ethanol $\left(40 \mathrm{~cm}^{3}\right)$ was added to equimolar quantity of the metal acetate in ethanol. Few drops of triethylamine were then added. The mixture was magnetically stirred and refluxed for $3 \mathrm{~h}$. The product formed was filtered and recrystallized from DMSO. NiL $2 \mathrm{H}_{2} \mathrm{O}$, selected FTIR data $\left(\mathrm{KBr}, \mathrm{v}_{\max }, \mathrm{cm}^{-1}\right): 3054(\mathrm{C}-\mathrm{H}, \mathrm{m}), 1606$ $(\mathrm{C}=\mathrm{N}, \mathrm{s}), 1239(\mathrm{C}-\mathrm{O}, \mathrm{s}), 550(\mathrm{Ni}-\mathrm{O}, \mathrm{w}) . \mathrm{CuL} \cdot \mathrm{H}_{2} \mathrm{O}$, selected FTIR data $\left(\mathrm{KBr}, v_{\max }, \mathrm{cm}^{-1}\right): 2345(\mathrm{C}-\mathrm{H}, \mathrm{s}), 1605(\mathrm{C}=\mathrm{N}, \mathrm{s})$, $1241(\mathrm{C}-\mathrm{O}, \mathrm{s}), 546(\mathrm{Zn}-\mathrm{O}, \mathrm{w}) \cdot \mathrm{ZnL} \cdot 2 \mathrm{H}_{2} \mathrm{O}$, selected FTIR data $\left(\mathrm{KBr}, v_{\max }, \mathrm{cm}^{-1}\right): 2532(\mathrm{C}-\mathrm{H}, \mathrm{m}), 1608(\mathrm{C}=\mathrm{N}, \mathrm{s}), 1240(\mathrm{C}-\mathrm{O}$, s), $548(\mathrm{Zn}-\mathrm{O}, \mathrm{w})$.

Antioxidant activity of the ligand and metal complexes by DPPH method: Free radical scavenging activity of the test compounds were determined by the 1,1-diphenyl picrylhydrazyl (DPPH) assay method ${ }^{12}$. Each of the Schiff bases and the metal complexes were dissolved in DMSO to obtain concentration of $1 \mathrm{mg} / \mathrm{mL}$. These stock solutions were then diluted to 5, 10, 25, 50 and $100 \mu \mathrm{g} / \mathrm{mL}$. Then, $200 \mu \mathrm{L}$ of each sample solution were combined with $50 \mu \mathrm{L}$ of DPPH $(0.3 \mathrm{mmL})$ in triplicate in a 96 -well microtitre plate. Final concentrations of the Schiff bases were 4, 8, 20, 40 and $80 \mu \mathrm{g}$ / $\mathrm{mL}$. The microtitre plate was incubated for $0.5 \mathrm{~h}$ at room temperature. The plate was then read at $515 \mathrm{~nm}$ for $3 \mathrm{~h}$ with 20 min intervals to reach a steady state against DMSO as a blank. The percentage DPPH quenched was calculated according to the equation:

$$
\text { DPPH quenched }(\%)=\frac{\left(\text { Abs. }_{\text {blank }}-\text { Abs. }_{\text {sample }}\right)}{\text { Abs. }_{\text {blank }}} \times 100
$$

the percentage free radical scavenging activity (inhibition \%) was plotted against concentration in $\mu \mathrm{g} / \mathrm{mL}$.

\section{RESULTS AND DISCUSSION}

The physical properties of the ligands and its metal complexes were listed in Table-1. Elemental analyses for the complexes confirm 1:1 metal to ligand stoichiometry. The compounds are very stable at room temperature in the solid state. The ligands are soluble in ethanol, methanol, acetone and high boiling point solvents like DMSO and DMF, whereas the complexes dissolves only in DMSO and DMF and not soluble in either ethanol or methanol.

IR spectra: The main stretching frequencies of the IR spectra of the ligand and complexes were shown in Table-2.

For the ligand, the spectra show the characteristics strong peak due to $\mathrm{C}=\mathrm{N}$ stretching at $1612 \mathrm{~cm}^{-1}$, indicating the formation of the Schiff base. Another strong peak at $1273 \mathrm{~cm}^{-1}$ is assigned to $\mathrm{C}-\mathrm{O}$ phenolic stretching, while a sharp weak peak at $3329 \mathrm{~cm}^{-1}$ is characteristic of free $-\mathrm{OH}$ group ${ }^{1}$. Other peaks bands in the region $1500-1000 \mathrm{~cm}^{-1}$ arise from benzene ring skeletal vibrations. The results strongly support the formation of the Schiff base ${ }^{13}$.

The IR spectra of the nickel complexes differ from that of the ligand. It is further noted that the - $\mathrm{OH}$ peak, observed for $\mathrm{H}_{2} \mathrm{~L}$ at $3329 \mathrm{~cm}^{-1}$, is now observed at $3401 \mathrm{~cm}^{-1}$ and is assigned to coordinated $\mathrm{H}_{2} \mathrm{O}$ molecules in agreement with the results from the elemental analyses. The peaks for $\mathrm{C}=\mathrm{N}$ at $1612 \mathrm{~cm}^{-1}$ and $\mathrm{C}-\mathrm{O}$ at $1273 \mathrm{~cm}^{-1}$ observed for $\mathrm{H}_{2} \mathrm{~L}$ have shifted

TABLE-1

PHYSICAL PROPERTIES OF THE LIGAND AND COMPLEXES

\begin{tabular}{|c|c|c|c|c|c|c|c|}
\hline \multirow{2}{*}{ Compound } & \multirow{2}{*}{ Formula } & \multirow{2}{*}{ Yield (\%) } & \multirow{2}{*}{ Colour } & \multirow{2}{*}{ f.w. } & \multicolumn{3}{|c|}{ Found. (calcd.) (\%) } \\
\hline & & & & & $\mathrm{C}$ & $\mathrm{H}$ & $\mathrm{N}$ \\
\hline $\mathrm{H}_{2} \mathrm{~L}$ & $\mathrm{C}_{39} \mathrm{H}_{49} \mathrm{~N}_{5} \mathrm{O}_{2}$ & 79 & Yellow & 619.89 & $75.49(76.35)$ & $7.90(7.21)$ & $11.29(11.87)$ \\
\hline $\mathrm{NiL} \cdot 2 \mathrm{H}_{2} \mathrm{O}$ & $\mathrm{NiC}_{39} \mathrm{H}_{51} \mathrm{~N}_{5} \mathrm{O}_{4}$ & 75 & Green & 712.58 & $65.67(66.57)$ & $7.15(6.46)$ & $9.82(10.15)$ \\
\hline $\mathrm{CuL} \cdot \mathrm{H}_{2} \mathrm{O}$ & $\mathrm{CuC}_{39} \mathrm{H}_{49} \mathrm{~N}_{5} \mathrm{O}_{3}$ & 78 & Green & 699.43 & $66.91(66.13)$ & $7.01(6.34)$ & $10.01(10.79)$ \\
\hline $\mathrm{ZnL} \cdot 2 \mathrm{H}_{2} \mathrm{O}$ & $\mathrm{ZnC}_{39} \mathrm{H}_{51} \mathrm{~N}_{5} \mathrm{O}_{4}$ & 75 & Yellow & 719.28 & $65.06(66.14)$ & $7.09(6.78)$ & $9.73(10.03)$ \\
\hline
\end{tabular}

TABLE-2

IR SPECTRAL BANDS $\left(\mathrm{cm}^{-1}\right)$ OF LIGAND AND ITS METAL COMPLEXES

\begin{tabular}{ccccccc}
\hline Compound & $v(\mathrm{O}-\mathrm{H})$ & $v(\mathrm{C}-\mathrm{H})$ Aliphatic & $v(\mathrm{C}=\mathrm{N})$ & $v(\mathrm{C}-\mathrm{O})$ & 1273 & $\mathrm{v}(\mathrm{M}-\mathrm{O})$ \\
\hline $\mathrm{H}_{2} \mathrm{~L}$ & 3329 & 2923 & 1612 & 1606 & 1239 & - \\
$\mathrm{NiL} \cdot 2 \mathrm{H}_{2} \mathrm{O}$ & $3401(\mathrm{H} 2 \mathrm{O})$ & 3054 & 1605 & 1241 & 550 & 523 \\
$\mathrm{CuL} \cdot \mathrm{H} 2 \mathrm{O}$ & $3400\left(\mathrm{H}_{2} \mathrm{O}\right)$ & 2345 & 1608 & 1240 & 496 & 546 \\
$\mathrm{ZnL} \cdot 2 \mathrm{H}_{2} \mathrm{O}$ & $3422(\mathrm{H} 2 \mathrm{O})$ & 2532 & 500 & 548 \\
\hline
\end{tabular}


to lower energy at 1606 and $1239 \mathrm{~cm}^{-1}$, respectively in NiL. These suggest that the phenolic oxygens and imino nitrogens are coordinated to $\mathrm{Ni}$ (II). Additionally, a new peak observed at $550 \mathrm{~cm}^{-1}$ may be assigned to Ni-O bond ${ }^{1}$.

The IR spectra for $\mathrm{Cu}(\mathrm{II})$ complexes shows the expected functional groups as previously discussed for the corresponding $\mathrm{Ni}(\mathrm{II})$ complex. The $\mathrm{C}=\mathrm{N}, \mathrm{C}-\mathrm{O}$ and $\mathrm{Cu}-\mathrm{O}$ peaks for [CuL6] $\cdot \mathrm{H}_{2} \mathrm{O}$ are at 1605,1241 and $546 \mathrm{~cm}^{-1}$, respectively. These are almost similar to those of the corresponding $\mathrm{Ni}(\mathrm{II})$ complex, suggesting similar bond strength.

The IR spectra for $\mathrm{Zn}(\mathrm{II})$ complexes shows the presence of all the expected functional groups. The wavenumbers of $\mathrm{C}=\mathrm{N}\left(1608 \mathrm{~cm}^{-1}\right)$ and $\mathrm{C}-\mathrm{O}\left(1240 \mathrm{~cm}^{-1}\right)$ groups are almost the same as for [CuL6 $\left.\left(\mathrm{H}_{2} \mathrm{O}\right)\right]\left(1605\right.$ and $1241 \mathrm{~cm}^{-1}$, respectively.

${ }^{1} \mathrm{H}$ NMR spectra: The ${ }^{1} \mathrm{H}$ NMR spectra for $\mathrm{H}_{2} \mathrm{~L}$ is consistent with the expected structural formula (Fig. 1). The singlet at $9.96 \mathrm{ppm}$ is due to phenolic hydrogen; a singlet at $8.24 \mathrm{ppm}$ is due to imino hydrogen; and a multiplet in the range 6.70-7.61 $\mathrm{ppm}$ is due to the aromatic hydrogens. Furthermore a singlet at $1.33 \mathrm{ppm}$ is due to tertiary butyl protons. The integration ratio for these hydrogens is $1: 1: 5.5$, respectively (expected ratio $=1: 1: 5.5)$ and supports the molecular symmetry for the Schiff base ${ }^{14}$.

${ }^{13}$ C NMR spectra: Further evidence for the proposed structure in Fig. 1 can be drawn from ${ }^{13} \mathrm{C}$ NMR spectra. The spectra shows 15 peaks, assigned as follows: 29 ppm (tertiary carbon atoms in the tert-butyl groups), $31.8 \mathrm{ppm}$ for the six methyl groups, 159.4 ppm C-OH, 167.91 ppm C=N, The aromatic carbons lie between 120.6-141.9 ppm. However, the expected number of peaks, after taking account of the symmetry of the structure, is ${ }^{14}$.

UV-visible spectra: The UV-VIS spectral data of the ligand and their complexes in DMSO are listed in Table-3. The UV-visible spectra for $\mathrm{H}_{2} \mathrm{~L}$ shows two moderately intense absorption bands at $288 \mathrm{~nm}\left(\varepsilon=2.1 \times 10^{4} \mathrm{M}^{-1} \mathrm{~cm}^{-1}\right)$ and 351 $\mathrm{nm}\left(\varepsilon=2.2 \times 10^{4} \mathrm{M}^{-1} \mathrm{~cm}^{-1}\right)$. The bands are assigned to $\pi-\pi^{*}$ transition of the aromatic ring and $n-\pi *$ transition of the azomethine chromophores, respectively. These values are in agreement with other Schiff bases reported in the literatures ${ }^{15,16}$.

\begin{tabular}{cccc}
\multicolumn{4}{c}{ TABLE-3 } \\
\multicolumn{4}{c}{ UV-VIS OF THE LIGAND AND COMPLEXES } \\
\hline \multirow{2}{*}{ Compound } & $\lambda_{\max }(\mathrm{nm})$ & $\varepsilon\left(\mathrm{M}^{-1} \mathrm{~cm}^{-1}\right)$ & Tentative assignment \\
\hline \multirow{2}{*}{$\mathrm{H}_{2} \mathrm{~L}$} & 288 & $2.1 \times 10^{4}$ & $\pi-\pi^{*}$ \\
& 351 & $2.2 \times 10^{4}$ & $\mathrm{n}-\pi^{*}$ \\
\hline \multirow{5}{*}{$\mathrm{NiL} \cdot 2 \mathrm{H}_{2} \mathrm{O}$} & 902 & 550 & ${ }^{3} \mathrm{~A}_{2 \mathrm{~g}} \rightarrow{ }^{3} \mathrm{~T}_{2 \mathrm{~g}}$ \\
& 736 & 257 & ${ }^{3} \mathrm{~A}_{2 \mathrm{~g}} \rightarrow{ }^{3} \mathrm{~T}_{1 \mathrm{~g}}(\mathrm{~F})$ \\
& 410 & $0.5 \times 10^{4}$ & $\mathrm{CT}$ \\
& 274 & $2.4 \times 10^{4}$ & $\pi-\pi^{*}$ \\
\multirow{2}{*}{$\mathrm{CuL} \cdot \mathrm{H} 2 \mathrm{O}$} & 348 & $0.7 \times 10^{4}$ & $\mathrm{n}-\pi^{*}$ \\
& 402 & $1.02 \times 10^{4}$ & $\mathrm{CT}$ \\
\multirow{2}{*}{$\mathrm{ZnL} \cdot 2 \mathrm{H}_{2} \mathrm{O}$} & 297 & $2.5 \times 10^{4}$ & $\pi-\pi^{*}$ \\
& 390 & $1.7 \times 10^{4}$ & $\mathrm{CT}$ \\
& 275 & $2.5 \times 10^{4}$ & $\pi-\pi^{*}$ \\
\hline
\end{tabular}

For nickel complexes the UV-VIS spectra exhibits weak $d-d$ bands $902\left(\varepsilon_{\max }=550 \mathrm{M}^{-1} \mathrm{~cm}^{-1}\right)$ and $736 \mathrm{~nm}\left(\varepsilon_{\max }=257 \mathrm{M}^{-1}\right.$ $\left.\mathrm{cm}^{-1}\right)$. These are consistent with an octahedral configuration at $\mathrm{Ni}(\mathrm{II})$ and using the Tanabe-Sugano diagram for $d^{8}$ complex, these bands are assigned to the transitions ${ }^{3} \mathrm{~A}_{2 \mathrm{~g}} \rightarrow{ }^{3} \mathrm{~T}_{2 \mathrm{~g}},{ }^{3} \mathrm{~A}_{2 \mathrm{~g}} \rightarrow$ ${ }^{3} \mathrm{~T}_{1 \mathrm{~g}}(\mathrm{~F})$, respectively ${ }^{17}$.

The peak at $410 \mathrm{~nm}\left(\varepsilon=0.5 \times 10^{4} \mathrm{M}^{-1} \mathrm{~cm}^{-1}\right)$ is assigned to metal-ligand charge transfer (MLCT). The spectrum is also compared with that of $\mathrm{H}_{2} \mathrm{~L}$. It is noted that the $\pi-\pi^{*}$ band observed for $\mathrm{H}_{2} \mathrm{~L}(288 \mathrm{~nm})$ remains shifted in the complex $(274 \mathrm{~nm})\left(\varepsilon=2.4 \times 10^{4} \mathrm{M}^{-1} \mathrm{~cm}^{-1}\right)$. However, the $\mathrm{n}-\pi^{*}$ band may be hidden under the strong MLCT band at $348 \mathrm{~nm}(\varepsilon=$ $\left.0.7 \times 10^{4} \mathrm{M}^{-1} \mathrm{~cm}^{-1}\right)$. Thus, this band is significantly red-shifted from ca. $300-400 \mathrm{~nm}$ as a result of complexation to the $\mathrm{Ni}$ (II). These results are in agreement with literature result indicating the formation of the complexes ${ }^{18}$.

The UV-visible spectra of the copper complexes shows a broad d-d peak at $670 \mathrm{~nm}\left(\varepsilon_{\max }=200 \mathrm{M}^{-1} \mathrm{~cm}^{-1}\right)$. Thus, $[\mathrm{CuL}$ $\left.\left(\mathrm{H}_{2} \mathrm{O}\right)\right]$ is a mononuclear square pyramidal complex. The $\pi-\pi^{*}$ and MLCT bands are at $297 \mathrm{~nm}\left(\varepsilon=2.5 \times 10^{4} \mathrm{M}^{-1} \mathrm{~cm}^{-1}\right)$ and $402 \mathrm{~nm}\left(\varepsilon=1.02 \times 10^{4} \mathrm{M}^{-1} \mathrm{~cm}^{-1}\right)$, respectively which are almost the same as for the corresponding $\mathrm{Ni}$ (II) complex (274, $410 \mathrm{~nm}$ ) and may be similarly explained.

The UV-visible spectra of the zinc complexes shows shows that the MLCT and $0-\pi *$ peaks $390 \mathrm{~nm}\left(\varepsilon=1.7 \times 10^{4} \mathrm{M}^{-1} \mathrm{~cm}^{-1}\right)$ and $275 \mathrm{~nm}\left(\varepsilon=2.5 \times 10^{4} \mathrm{M}^{-1} \mathrm{~cm}^{-1}\right)$ are at almost the same energy as the corresponding peaks for $\left[\mathrm{CuL}\left(\mathrm{H}_{2} \mathrm{O}\right)\right](402,297$ $\mathrm{nm}$. Thus, both metal ions have insignificant effect on the electronic transitions of the organic moiety. The MLCT peak is normally observed from 348-323 nm for Zn(II) complexes, involving electronic transitions from the full $\mathrm{d}$ orbitals of the metal ion $\left(3 d^{10}\right)$ to antibonding orbitals of the ligand ${ }^{19}$.

Thermal analysis (TGA): The thermal decomposition process for $\mathrm{Ni}$ (II), $\mathrm{Cu}$ (II) and $\mathrm{Zn}$ (II) complexes were examined and assessed in the temperature range $50-900^{\circ} \mathrm{C}$. The obtained themo-analytical data from the thermogravimetric curves were summarized in Table-4.

\begin{tabular}{cccc}
\multicolumn{5}{c}{ TABLE-4 } \\
\multicolumn{4}{c}{ THERMAL } \\
\multirow{2}{*}{ Compound } & Step & $\begin{array}{c}\text { Decomposition } \\
\mathrm{T}_{\max }\left({ }^{\circ} \mathrm{C}\right)\end{array}$ & $\begin{array}{c}\text { Eliminated } \\
\text { species }\end{array}$ \\
& First & 130 & $2 \mathrm{H}_{2} \mathrm{O}$ \\
$\mathrm{NiL} \cdot 2 \mathrm{H}_{2} \mathrm{O}$ & Second & 300 & Ligand \\
& Third & 875 & Residue $(\mathrm{NiO})$ \\
\hline \multirow{2}{*}{$\mathrm{CuL} \cdot \mathrm{H}_{2} \mathrm{O}$} & First & 140 & $\mathrm{H}_{2} \mathrm{O}$ \\
& Second & 310 & Ligand \\
& Third & 650 & Residue $(\mathrm{CuO})$ \\
\hline \multirow{2}{*}{$\mathrm{ZnL} \cdot 2 \mathrm{H}_{2} \mathrm{O}$} & First & 150 & $2 \mathrm{H}_{2} \mathrm{O}$ \\
& Second & 340 & Ligand \\
& Third & 850 & Residue $(\mathrm{ZnO})$ \\
\hline
\end{tabular}

The data obtained indicate that nickel complexes are thermally stable up to $246^{\circ} \mathrm{C}$. The first weight loss of $2.7 \%$ at $130{ }^{\circ} \mathrm{C}$ corresponds to the loss of coordinated $\mathrm{H}_{2} \mathrm{O}$ molecules (expected, $5.3 \%$ ). The next step represents a total weight loss of $87.4 \%$ and is assigned to the decomposition of the ligand (expected, $87 \%$ ). The amount of residue at $875{ }^{\circ} \mathrm{C}$ is $9.6 \%$. Assuming that the residue is $\mathrm{NiO}$, the expected value is $10.4 \%$, which is within the acceptable experimental error.

The data obtained indicate that copper complexes are thermally stable up to $250^{\circ} \mathrm{C}$. Thus, it is as thermally stable as $\left[\mathrm{NiL}\left(\mathrm{H}_{2} \mathrm{O}\right)_{2}\right]\left(246^{\circ} \mathrm{C}\right)$.

The first weight loss of $3.5 \%$ at $140{ }^{\circ} \mathrm{C}$ corresponds to the loss of coordinated $\mathrm{H}_{2} \mathrm{O}$ molecule (expected, $2.5 \%$ ). The 
next step represents a total weight loss of $83.3 \%$ and is assigned to the decomposition of the ligand (expected, $88.6 \%$ ). The amount of residue at about $650{ }^{\circ} \mathrm{C}$ is $13.2 \%$. Assuming that the residue is $\mathrm{CuO}$, the expected value is $11.1 \%$. Thus, the thermal properties of $\left[\mathrm{CuL}\left(\mathrm{H}_{2} \mathrm{O}\right)\right]$ is similar from that of $\left[\mathrm{NiL}\left(\mathrm{H}_{2} \mathrm{O}\right)_{2}\right]$.

The data obtained indicate that zinc complexes are thermally stable up to $245^{\circ} \mathrm{C}$. Thus, it is as themally stable as $\left[\mathrm{CuL}\left(\mathrm{H}_{2} \mathrm{O}\right)\right]\left(250{ }^{\circ} \mathrm{C}\right)$.

The first weight loss of $3.7 \%$ at $150{ }^{\circ} \mathrm{C}$ corresponds to the loss of coordinated $\mathrm{H}_{2} \mathrm{O}$ molecules (expected, $5.1 \%$ ). The next step represents a total weight loss of $86.1 \%$ and is assigned to the decomposition of the ligand (expected, $86.2 \%$ ). The amount of residue at $850{ }^{\circ} \mathrm{C}$ is $10.2 \%$. Assuming that the residue is $\mathrm{ZnO}$, the expected value is $11.3 \%$, which is within the acceptable experimental error.

Antioxidant activity: The antioxidant activity of the ligand and their nickel, copper and zinc complexes was measured in terms of their hydrogen donating or radical scavenging ability by UV-visible spectrophotometer using the stable DPPH radical.

It has been shown that the free radical scavenging ability of the novel Schiff bases is dependent on the chemical substituents attached to the aromatic rings and generally the antioxidant activity of all compounds was increased with increase of their concentration.

The prepared Schiff bases seem to have a very efficient conjugated system, which means that this type of compounds may play important role as antioxidant agents. In addition, the presence of hydroxyl groups, which are attached to aromatic rings can increase the conjugated systems and consequently increase the antioxidant activity of the corresponding Schiff bases. It is known that the antioxidant activity in phenolic compounds can take place through either of two mechanisms i.e., hydrogen atom transfer and electron donating ability ${ }^{20}$. The mechanism, which occurs here could be similar to that mechanism, which occurs in hydroxy chalcones and hydroxy flavonoids derivatives ${ }^{21,22}$.

\section{Conclusion}

Schiff base ligand derived from 4-phenyl-1,3,5-triazine2,6-diamine and 3,5-di-tert-butylsalicylaldehyde with their nickel, copper and zinc complexes have been synthesised and characterized. The antioxidant studies of the compounds reveal that the ligands are more effective antioxidants than their metal complexes. They mainly act as a hydrogen atom transferring antioxidants in an oxidative process. However, chelating to the metal ions suppresses this property through coordination to the metal centre, thus hampers hydrogen atom abstraction through deprotonation.

\section{ACKNOWLEDGEMENTS}

The authors thankfully acknowledged the support from University of Malaya, IPPP grant No. P5340/2009C.

\section{REFERENCES}

1. L. Sacconi, Coord. Chem. Rev, 1, 126 (1966).

2. L.F. Lindoy, Quart Chem. Rev, 1, 379 (1971)

3. S. Yamanda and A. Takeuchi, Coord. Chem. Rev., 43, 187 (1982).

4. Y. Tor, J. Libman, A. Shanzer and S. Lifson, J. Am. Chem. Soc., 109, 6517 (1987).

5. R. Grigg and P. Armstrong, Tetrahedron, 45, 23 (1989).

6. B.S. Holla, B. Veerendra, M.K. Shivananda and B. Poojary, Eur. J. Med. Chem., 38, 759 (2003).

7. R.V. Chambhare, B.G. Khadse, A.S. Bobde and R.H. Bahekar, Eur. J. Med. Chem., 38, 89 (2003).

8. B.S. Holla, K.V. Malini, B.S. Rao, B.K. Sarojini and N.S. Kumari, Eur. J. Med. Chem., 38, 313 (2003).

9. A. Ali, N. Abdullah, M.J. Maah and I.M. Mustafa, Asian J. Chem., 24, 5063 (2012).

10. Y. Wang, Z.-Y. Yang and B.-D. Wang, Transition Met. Chem., 30, 879 (2005).

11. L. Araya, J. Vargas and J. Costamagna, Transition Met. Chem., 11, 312 (1986).

12. W. Brand-Williams, M.E. Cuvelier and C. Berset, LWT-Food Sci. Technol., 28, 25 (1995).

13. B.S. Garg and D.N. Kunar, Spectrochim. Acta A, 59, 229 (2003).

14. Z.L. Yuan, Q. Long, Z. Xue Ziang, B. Xue Zhy, F. Lindoy and G. Wei, Polyhedron, 27, 344 (2008).

15. R.S. Downing and F.L. Urbach, J. Am. Chem. Soc., 91/22, 5977 (1969).

16. A. Pagini, M. Gullotti and R. Vgo, J. Chem. Soc. Dalton Transition, 4, 346 (1977).

17. L. Sacconi, Transition Met. Chem., 61, 943 (1968).

18. D. Santo, D. Bella, I. Fragala, N. Leonardi and S. Sortino, Inorg. Chim. Acta, 357, 3865 (2004).

19. C. Alaaddin, Y. Ibrahim, O. Habibe and A. Misir, Transition Met. Chem., 27, 171 (2002).

20. W. Jen, S.F. Sun, W. Cao, Y. Liang and J.R. Song, J. Mol. Struct., 918, 194 (2009).

21. P. Cos, L. Ying, M. Calomme, J.P. Hu, K. Cimanga and B. Van Poel, J. Nat. Prod., 61, 71 (1998).

22. V.A. Sabe, D.J. Van den Berg, M.N.J.L. Tromp, D.H. Griffioen, W.J.F. Van der Vijgh and A. Bast, Free Radic. Biol. Med., 20, 331 (1996). 